日心第74回大会 $(2010)$

第2日 9月21日（火） $9: 30 \sim 11: 30$ A002

\title{
WS040 神経心理学の新しい展望
}

一社会的認知への仮説検証的アプローチー

$\begin{array}{llrr}\text { 企 画 者 } & \text { 千葉大学 } & \text { 小山 } & \text { 慎一 } \\ \text { 司 会 者 } & \text { 千葉大学 } & \text { 小山 } & \text { 慎一 } \\ \text { 話題提供者 } & \text { 千葉大学 } & \text { 小山 } & \text { 慎一 } \\ \text { 話題提供者 } & \text { 中央大学 } & \text { 緑川 } & \text { 晶 } \\ \text { 話題提供者 } & \text { 名古屋大学 } & \text { 鈴木 } & \text { 敦命 } \\ \text { 話題提供者 } & \text { (独行) 国立精神・神経医療研究センター } & \text { 本間 } & \text { 元康 }\end{array}$

\section{概 要}

本ワークショップの企画者らは神経心理学者として患者の症状の理解を目指すとともに、心理学者として 心の働きに関するモデルを構築することを目指してきた。すなわち、患者の症状の分析は、病気の理解のプ ロセスであると同時に、人間の心理的・神経的モデル検証のプロセスでもあった。今回のワークショップで は、顔認知、模倣、同調行動等の社会的認知に焦点をあて、症状とモデルの関係について考察する。 